\title{
Metal Casting Engineering Courses Assisted by Digital Smart Modules: An Assessment of Experts and Users
}

\author{
Sutopo \\ Department of Mechanical Engineering Education \\ Faculty of Engineering, Universitas Negeri Yogyakarta, \\ Yogyakarta, Indonesia

\section{Bayu Rahmat Setiadi} \\ Department of Mechanical Engineering Education \\ Faculty of Engineering, Universitas Negeri Yogyakarta, \\ Yogyakarta, Indonesia
}

DOI: https://doi.org/10.36941/ajis-2020-0085

\section{Abstract}

This study aims to: (1) produce a digital smart module (DSM) as a learning resource in aluminum metal casting learning; (2) determine the feasibility of the developed DSM; and (3) determine the user's response to the developed DSM. The current research and development build upon the development procedures proposed by Borg $\mathcal{E}$ Gall. The research subjects consisted of material experts, media experts, lecturers, and students. Development procedures in this study include need analysis, expert validation, and user response tests. Data collection was carried out by interview and questionnaire. The instruments used are interview guidelines, product validation questionnaire sheets for material and media experts, and lecturer and student response questionnaire sheets. The questionnaire uses a four-point Likert scale. The data obtained were analyzed using quantitative descriptive method. The results of this study are: (1) a DSM for aluminum metal casting learning, (2) the developed module has met the eligibility criteria based on the assessment of material experts and media experts. Material expert assessment obtained a percentage of $93 \%$ included in the excellent category and media expert evaluation obtained a percentage of $93.4 \%$ included in the excellent category, and (3) overall user response to the developed DSM is excellent, lecturers response has a percentage of $95 \%$ included in the excellent category while the students response students has a percentage of $90 \%$ included in the excellent category.

Keywords: aluminum metal casting; digital smart module; interactive multimedia; mobile learning

\section{Introduction}

Education is the most crucial part of the country. The quality of education influences both developed and developing countries (Dumciuviene, 2015). Indonesia, as a developing country, also has an education system as an effort to implement quality education. Engineering Diploma (ED) is a formal education level which implements vocational secondary education programs as a continuation of vocational high school, or other forms of equivalent or continuation of learning program (Sudira, 2014). ED is also tasked with providing learning and experience for students so that graduated 
students are ready and able to work according to the field of ED.

The Mechanical Engineering Diploma (MED) learning organization is oriented to prepare students to be ready to face the working world and produce competitive graduates in the working world (Estriyanto, Kersten, Pardjono, \& Sofyan, 2017). Graduated MED students are expected to have the necessary skills that are integrated between cognitive, affective, and psychomotor aspects. One of the most important lessons in MED related to the working world is metal casting (Perzyk \& Kozlowski, 2018). Metal casting technique is essential learning and must be a field study to students in mechanical engineering skills program. To achieve this goal the metal casting learning process implemented in schools must be carried out effectively and efficiently. Appropriate learning media is needed to support the achievement of this goal. Electronic-based learning media is an answer to the integration of technology in 21st-century learning (Adam \& Suprapto, 2019; Setuju, Setiadi, Rantnawati, \& Widowati, 2019).

One of the learning media that is relevant to the current development to support learning is learning media in the form of digital smart modules (DSM). The module is in electronic form, so it has a digital concept design called an electronic module which is equipped with interactive and fun features (Karnain, Rahman, Surat, \& Ali, 2019). However, learning media in the form of DSM is needed to support the effectiveness of learning, deliver material and facilitate the learning of metal casting techniques at VHS (Vocational High School). Multimedia based learning can be a practical thing, a solution to improve knowledge and character (Prasetya \& Hirashima, 2018). Besides, there is a vital urgency in instilling electronic-based learning into learning platforms (Hwang, Chen, Dung, \& Yang, 2007; Zhai, 2018).

\section{Review of Literature}

\subsection{Interactive multimedia}

The success of the learning process is closely related to the availability of facilities and infrastructure owned by the school. The facilities referred to are learning media that can support the learning process(Yarkova, Cherkasova, Timofeeva, Cherkasov, \& Yarkov, 2017). Media is a component of communication as a messenger from the communicator to the communicant (Heinich, Molenda, Russell, \& Smaldino, 2012). Today, Science and Technology is developing rapidly and development is aimed at the world of education. Learning by utilizing technological developments aims to create a dynamic and interactive learning environment inside and outside the classroom (Gendall, 20o8; Setuju, Ratnawati, Wijayanti, Widodo, \& Setiadi, 2020). Therefore, the use of instructional media that includes innovations and interactive features must be considered and adjusted to the current development so that the learning process can be carried out optimally.

Interactive media have become unique in the method of presentation, which involves visuals, sound and video and settings through a computer (Dugan, 1955; Edgar, 1969). Interactivity in learning occurs because of interactions between students with the environment, students with students, and students with lecturers. The interactive principle has the meaning of teaching activities that not only convey lecturer knowledge to students but teach as a step to regulate the environment, thereby stimulating students to learn.

Based on the narrative above, it can be concluded that interactive learning media is part of an effective way to prevent students from boredom and to stimulate students to always to want to learn. The selection of the right media will influence success in learning. Media selection considers the results of preliminary analysis both for the students' conditions and needs, so that the selection is appropriate, and the learning objectives will be achieved (Reiser \& Gagné, 1982). In addition to paying attention from the students' point of view, it is also necessary to pay attention to the ability to arrange the media.

Interactive multimedia can be used in all areas of human life, especially with the rapid development of technology and the needs of everyone. Information exchange is now more effective 
and easier to understand. There are six interactive multimedia criteria (Asrial, Syahrial, Kurniawan, Perdana, \& Nugroho, 2019; Li \& Ren, 2018; Prasetya \& Hirashima, 2018), namely (1) ease of navigation, (2) content of cognition, (3) knowledge and information presentation, (4) media integrate aspects and skills, (5) has a good artistic and aesthetic appearance, and (6) able to provide the learning needed by students. Multimedia can be in the form of text, sound, graphics, animation, and video that aim to convey information. With the elements that form interactive multimedia, it has strengthened the information that will be obtained. The use of various types of media such as text, images, sound, video, animation, graphics, and interactive elements to convey information will make learning more exciting and meaningful.

\subsection{Digital Smart Module}

The module is designed as a complete learning resource and can stand alone (Enke, Kraft, \& Metternich, 2015). It consists of learning materials that are designed systematically to help students in achieving learning objectives that have been determined. Modules are instructional media that are arranged systematically with easy to understand language and can be used to learn independently with minimal guidance from educators (Biasutti, 2011; Butcher, Davies, \& Highton, 2006). Its use in the teaching and learning process aims so that students can learn independently and lecturer only acts as facilitator.

The digital smart module (DSM) is a printed form of a module that can be operated on a computer or smart phone that is designed with software assistance (Darmaji et al., 2019; Hsu \& Chen, 2010; Bayu Rahmat Setiadi et al., 2019). DSM is a portable device that displays information and can be navigated by its users. Digital modules can be linked to many features to get specific information that aims to increase more experience. DSM is equipped with videos, simulations, quizzes with live assessments and animations so that students can know the level of mastery of learning with interactive self-evaluation. These characteristics are important for students because they have the potential to increase student motivation and interest through operations using computers or smart phones. There is a vital urgency in linking electronic-based learning to learning platforms (Darma, Setyadi, Wilujeng, Jumadi, \& Kuswanto, 2019). The difference between the printed module and the electronic module is seen in the physical presentation format, but the electronic module has more features, especially in terms of interactive (Vina Serevina, Sunaryo, Raihanati, I Made Astra, 2018).

The principle of writing modules is oriented towards students' independent learning (B R Setiadi, Nuryanto, \& Ahmad, 2020). The module encourages students to study the module individually or in groups without prior assistance from the lecturer so that the lecturer only acts as a facilitator in learning. The grammar in the module is expected to make it easier for students to understand the material available without any difficulty. Therefore, the language used needs to be adjusted to the students' ability.

The above principle of producing modules is needed to be a guideline for writing. The application of this principle is intended so that modules are designed to produce good communication between modules as learning objects to students as users. As a supporting media, the module has two aspects of supporting the delivery of learning material to students. The first aspect is the verbal aspect related to the use of language, sentences, and letters, which can clarify the material in the module. The second aspect is visuals related to the selection and presentation of pictures or text elements.

\section{Method}

\subsection{Development design}

This research and development build upon the development procedure proposed by Borg \& Gall (Borg \& Gall, 1983). Based on the development procedure, several methods are adapted to the 
direction of development. The development procedures used to conduct research and development of metal casting interactive electronic modules can be seen in Figure 1:

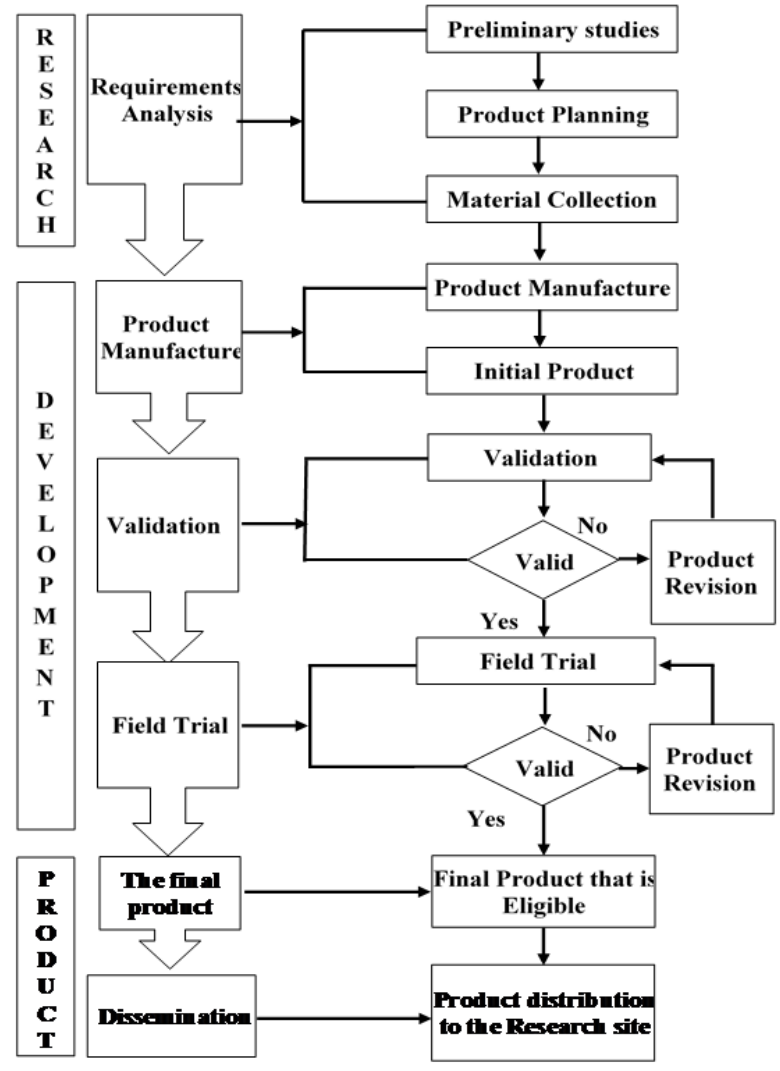

Fig. 1: Development steps

\subsection{Product trial design}

This process is divided into two stages, namely the validation stage by experts and field trials (Mirzianov, Mitasiunas, Novickis, \& Ragaisis, 2016). Validation is carried out by material experts and media experts, aiming to determine the feasibility of interactive electronic modules. In contrast, the field trials were conducted for lecturers and students, aimed at knowing the user's response to the interactive electronic module.

\subsection{Data collection}

The instruments used in this research and development are interview guidelines and questionnaire evaluation sheets. Interview guidelines are used for obtaining preliminary data from lecturers and students. The evaluation sheet questionnaire used was divided into two types, namely: (1) product feasibility questionnaire by material experts and media experts, and (2) user response questionnaire, namely lecturers and students. 


\subsection{Data analysis technique}

Preliminary data in the research and development process conducted with observation and interviews (during needs analysis). The results are analyzed with descriptive techniques, and these results are used as input for the design and manufacture of products. Data analysis of the results of validation and user responses was carried out with quantitative descriptive analysis; quantitative data obtained from the questionnaire in the form of scores were then interpreted with qualitative sentences based on the rating scale used [7].

$$
\text { Percentage of rating }(\%)=\frac{\text { Score obtained }}{\text { Expected score }} \times 100 \%
$$

Table 1: Percentage scale

\begin{tabular}{|c|c|c|}
\hline Percentage Earnings & Value Scale & Category \\
\hline $76-100 \%$ & 4 & Excellent \\
\hline $56-75 \%$ & 3 & Good \\
\hline $40-55 \%$ & 2 & Enough \\
\hline $0-39 \%$ & 1 & Not good \\
\hline
\end{tabular}

Table 1 determines the value/category of the product being developed. Categories are considered suitable for use if they meet the "Good" minimum standards.

\section{Results and Discussion}

The interactive electronic module on learning aluminum metal casting using a Liquified Petroleum Gas (LPG) Crucible Furnace consists of 4 learning activities. The contents of teaching materials are identified based on the following: (1) core competencies/essential competencies, (2) syllabus and learning implementation design, (3) supporting lecturers, (4) experts in the field of casting, and (5) furnace infrastructure used. Electronic modules totaling 90 pages with the material can be seen in Table 2:

Table 2: Percentage scale

\begin{tabular}{|l|l|}
\hline Activities & Learning Materials \\
\hline Learning Activities 1 Pattern & 1. Pattern \\
& 2. Pattern Function \\
& 3. Types of Patterns \\
& 4. Pattern Making Material \\
& 5. How to Make Patterns \\
\hline Learning Activities 2 Sand Casting & 1. Mold Sand Requirements \\
& 2. Kinds of Sand Mold \\
& 3. Greensand Mold \\
& 4. Types of Greensand Mold \\
& 5. The Properties of Greensand Mold \\
& 6. Characteristics of Greensand Mold \\
& 7. Sand Printing Process \\
8. Greensand Mold Testing \\
9. Strengths and Weaknesses of Greensand
\end{tabular}




\begin{tabular}{|l|l|}
\hline Learning Activities 4 Metal Smelting with & 1. Crucible Furnace \\
Crucible Furnaces & 2. Crucible Furnace Parts \\
& 3. Occupational Health and Safety in Casting \\
& 4. The Principle of Crucible Furnace Work \\
& 5. How to Operate Crucible Furnaces \\
& 6. How to Make a Mold \\
& 7. Metal Castings Process \\
& 8. How to finish the casting results \\
9. Crucible Furnace Maintenance
\end{tabular}

This product development build upon the development procedures proposed by Borg and Gall(Borg \& Gall, 1983; Sugiyono, 2013). Following the development procedure, several steps are adjusted to the needs of researchers as the direction of development, namely as follows: (1) needs analysis, (2) manufacturing of products, (3) validation, (4) field trials, (5) final products, and (6) dissemination (Richey \& Klein, 2005). The interactive electronic module can also load many features including links, movies, images, quizzes, sound, flash, YouTube, and text) and has several other supporting features to help facilitate users and navigation, namely: thumbnails, go to pages, zoom, full screen, bookmarks, add annotations, crop, switch language, sound, search, print, share by email, social share, return home, auto flip, select text, about, and help. The interactive electronic module developed can be used via a smart phone (Figure 2 ) or a computer (Figure 3 ).

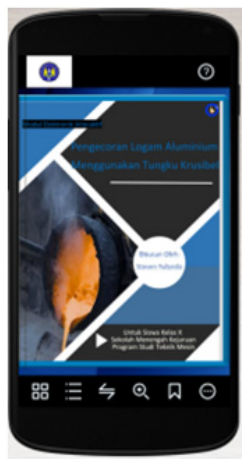

Fig. 2: Module display on the smart phone

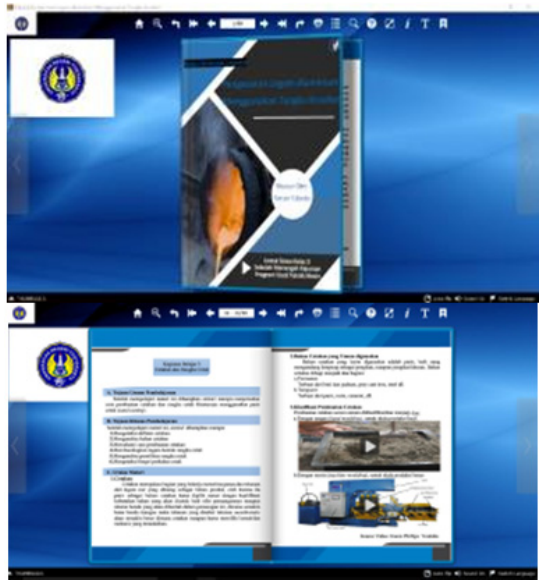

Fig. 3: Module display on the computer 
The product development process involves several experts, namely material experts, media experts, and module experts (when conducting analyzing needs) as well as users, in this case, lecturers and students. Product trials are divided into two stages, namely the validation stage by experts and field trials. Expert validation was conducted with material experts and media experts to determine the module's suitability while field trials are conducted for subject matter lecturers and students to find out the user's response to the developed modules.

\subsection{Content Validity}

This validation is to determine the level of eligibility of the DSM that was developed in the material aspects before field trials. This validation was carried out by expert lecturers in the field of aluminum metal casting learning in the Department of Mechanical Engineering Education. The validation is done by reviewing the DSM based on the syllabus, lesson plans, job sheets and assessment questionnaire that has been developed. The assessment conducted by material experts includes several aspects, namely: (1) self-instruction, (2) self-contained, (3) stand-alone, (4) adaptive, and (5) user-friendly. Based on the total average, it can be seen that $93 \%$ of DSM are declared valid by material experts.

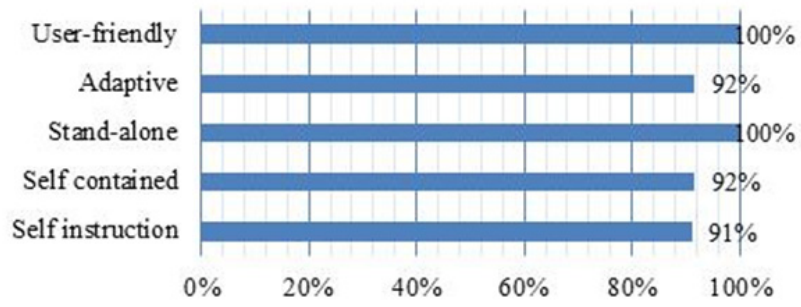

Fig. 4: Content validity by aluminum metal casting experts

\subsection{Media validity}

The validation of media experts aims to determine the level of eligibility of the developed DSM in media aspect before field trials are conducted. Expert lecturers conducted this validation in the field of learning media in the Department of Mechanical Engineering Education. Validation is done by providing DSM with validated content. The assessment conducted by media experts includes several aspects, namely: (1) verbal, (2) visual, (3) programming, and (4) module framework. Based on the total average, it can be seen that $93.4 \%$ of DSM was declared valid by media experts.

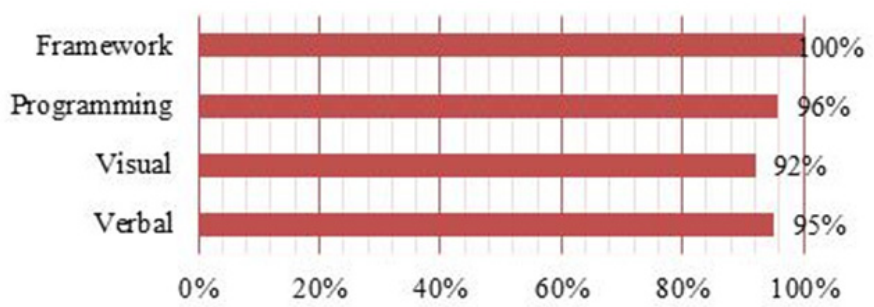

Fig. 5: Media validity by learning media experts 


\subsection{Field test}

After being validated by experts and revising the product according to the suggestions and input of material experts and media experts, the product is ready to be carried out for field trials to determine user responses to the developed DSM. This test is carried out for aluminum metal casting subjects.

The first step is testing the response of the subject matter lecturer. This test aims to determine the response of lecturers as users of the developed DSM. This test is carried out by providing DSM and paying attention to syllabus, lesson plans, job sheets and assessment questionnaires that has been developed by researchers. The assessment conducted by the lecturer includes several aspects, namely: (1) the quality of the material, (2) the format of the media display, and (3) the grammar content.

The field test was also conducted by looking at students' responses to the developed media. This test aims to determine the response of students as users of the developed DSM. This test was conducted on 32 students in MED of Universitas Negeri Yogyakarta. Assessments made by students include several aspects, namely: (1) presentation of material, (2) media appearance, and (3) usefulness. The following are tabulations of two field test subjects.

Table 3: Field Test Result

\begin{tabular}{|c|c|c|c|c|c|c|c|c|c|c|}
\hline \multirow{2}{*}{\multicolumn{2}{|c|}{ Num. }} & \multirow{2}{*}{$\begin{array}{l}\text { Assessment } \\
\text { Aspects }\end{array}$} & \multicolumn{4}{|c|}{ Freq. } & \multirow{3}{*}{$\begin{array}{c}\text { Number of Questions } \\
11 \\
\end{array}$} & \multirow{3}{*}{ Xt } & \multirow{3}{*}{ Yt } & \multirow{3}{*}{$\begin{array}{l}\% \\
95 \\
\end{array}$} \\
\hline & & & \multirow{2}{*}{$\mathbf{1}$} & \multirow{2}{*}{\begin{tabular}{|l|}
2 \\
0
\end{tabular}} & \multirow{2}{*}{\begin{tabular}{|l|}
3 \\
2 \\
\end{tabular}} & \multirow{2}{*}{4} & & & & \\
\hline & 1 & Quality of Material & & & & & & & & \\
\hline 总 & 2 & Media Display Format & o & o & 2 & 11 & 13 & 50 & 52 & 96 \\
\hline $\mathscr{\varpi}$ & 3 & Use of Language & o & o & 2 & 4 & 6 & 22 & 24 & 92 \\
\hline \multicolumn{7}{|c|}{ Sum } & 30 & 114 & 120 & 95 \\
\hline \multirow{3}{*}{ 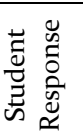 } & 1 & Presentation of Material & 1 & 12 & 113 & 258 & 384 & 1396 & 1536 & 91 \\
\hline & 2 & Media Display & 1 & 14 & 125 & 212 & 352 & 1252 & 1408 & 89 \\
\hline & 3 & Usefulness & o & 4 & 70 & 150 & 224 & 818 & 896 & 91 \\
\hline \multicolumn{7}{|c|}{ Sum } & 960 & 3466 & 3840 & 90 \\
\hline
\end{tabular}

\subsection{Effectiveness test}

Pretest and posttest aim to find out the effectiveness of the products developed in learning process. The pretest was done before applying the developed product in aluminum metal casting learning, whereas the posttest was done after applying DSM. This test has 20 multiple choice questions made based on the syllabus and material studied. This test was carried out on 32 students at MED of Universitas Negeri Yogyakarta.

Based on the calculation analysis, the data inform that the average pretest results of students before using the developed DSM are 48.75 while the posttest results after using the developed DSM are 85.93. Besides seeing the obtained average value, pretest and posttest results are also seen from the gain score as follows.

$$
\begin{aligned}
& \mathrm{g}=\frac{\text { Spost }- \text { Spre }}{\text { Smax }- \text { Spre }} \\
& \mathrm{g}=\frac{85.93-48.75}{100-48.75} \\
& \mathrm{~g}=\frac{37.18}{51.25}=0.72
\end{aligned}
$$

The calculation results shows a gain value of 0.72 and it is in the high category. A comparison of the results of the pretest and posttest can be seen in the following table. 
Table 4: Comparison of Pretest and Posttest Results

\begin{tabular}{|c|l|c|c|}
\hline Num. & Category & Pretest & Posttest \\
\hline 1 & Lowest score & 35.00 & 80.00 \\
\hline 2 & The highest score & 65.00 & 90.00 \\
\hline 3 & Mean & 48.75 & 85.93 \\
\hline Gain score & \multicolumn{2}{|c|}{0.72} \\
\hline Gain score category & \multicolumn{2}{|c|}{} \\
\hline
\end{tabular}

Based on the analysis of product development data, experts and users it is noted that this module is suitable for use in learning. Material expert assessment obtained a percentage of $93 \%$ included in the "excellent" category, and media expert evaluation obtained a percentage of $93.4 \%$ included in the "excellent" category. The user response to interactive electronic modules on learning metal casting, in this case, the lecturers' and students' response, obtaining a percentage of $95 \%$ for lecturer responses included in the "excellent" category while the students' response obtained a percentage of 90\% included in the "excellent" category. It shows that as a product, DSM is eligible to be disseminated for learning in other metal casting classes.

Digital smart modules developed in this study have several advantages (Hsu \& Chen, 2010; Johnston, 2010), including:

1. DSM can be run on computers or smartphones on all Operating Systems (OS).

2. It uses links, movies, images, quizzes, sound, flash, YouTube, and text in delivering the material

3. Has other supporting features to help facilitate users and navigation, namely: thumbnails, go to page, zoom, full screen, bookmarks, add annotations, crop, switch language, sound, search, print, share by email, social share, return home, auto flip, select text, about, and help.

4. It can be used anytime and anywhere with high flexibility and also can be run offline or online.

5. With this module, the distribution of learning materials to students becomes more comfortable.

6. Abstract material can be more explicit.

7. No cost for printing books.

8. Learning is done with a comfortable and pleasant atmosphere so that it attracts learning interest.

9. Students become more involved in learning and can learn according to individual learning speed.

10. Learning time becomes more active, and students can learn the module first anywhere.

\section{Conclusion}

The digital smart module on metal casting learning has been produced through the following development procedures: (1) needs analysis, (2) manufacturing of products, (3) validation, (4) field trials, (5) final products, and (6) dissemination. The DSM on metal casting learning has fulfilled the eligibility criteria in the material and media aspects, so it is suitable for use. Material expert assessment obtained a percentage of $93 \%$ included in the "excellent" category, and media expert evaluation obtained a percentage of $93.4 \%$ included in the "excellent" category. The user response to interactive electronic modules on learning metal casting, in this case, the lecturers' and students' response, obtaining a percentage of $95 \%$ for lecturer responses included in the "excellent" category while the students' response obtained a percentage of $90 \%$ included in the "excellent" category. 


\section{Acknowledgment}

We thank Universitas Negeri Yogyakarta (UNY) for providing support and access to information to publish our research results in this journal. The researcher also feels thankful to UNY for providing research assistance and publication fee.

\section{References}

Adam, A. S., \& Suprapto, N. (2019). One-stop physics E-Book package development for senior high school learning media. International Journal of Emerging Technologies in Learning, 14(19), 150-158. https://doi.org/10.3991/ijet.v14i1910761

Asrial, Syahrial, Kurniawan, D. A., Perdana, R., \& Nugroho, P. (2019). Supporting Technology 4.0: Ethoconstructivist multimedia for elementary schools. International Journal of Online and Biomedical Engineering, 15(14), 54-66. https://doi.org/10.3991/ijoe.v15i14.11365

Biasutti, M. (2011). The student experience of a collaborative e-learning university module. Computers and Education. https://doi.org/10.1016/j.compedu.2011.04.006

Borg, W. R., \& Gall, M. D. (1983). Educational Research: An Introduction. New York: Longman.: Longman.

Butcher, C., Davies, C., \& Highton, M. (2006). Designing learning: From module outline to effective teaching. Designing Learning: From Module Outline to Effective Teaching. https://doi.org/10.4324/9780203968482

Darma, R. S., Setyadi, A., Wilujeng, I., Jumadi, \& Kuswanto, H. (2019). Multimedia Learning Module Development based on SIGIL Software in Physics Learning. In Journal of Physics: Conference Series. https://doi.org/10.1088/1742-6596/1233/1/012042

Darmaji, Astalini, Kurniawan, D. A., Parasdila, H., Iridianti, Susbiyanto, ... Ikhlas, M. (2019). E-Module based problem solving in basic physics practicum for science process skills. International Journal of Online and Biomedical Engineering, 15(15), 4-17. https://doi.org/10.3991/ijoe.v15i15.10942

Dugan, J. E. (1955). Audio-Visual Methods in Teaching, Revised Edition, by Edgar Dale. The Dryden Press, 520 pp. \$6.25. The Educational Forum, 19(2), 244-244. https://doi.org/10.108o/oo131725509341801

Dumciuviene, D. (2015). The Impact of Education Policy to Country Economic Development. Procedia - Social and Behavioral Sciences. https://doi.org/10.1016/j.sbspro.2015.04.302

Edgar, D. (1969). Audio visual methods in teaching, 108. Retrieved from http://www.queensu.ca /teachingandlearning/modules/active/documents/Dales_Cone_of_Experience_summary.pdf

Enke, J., Kraft, K., \& Metternich, J. (2015). Competency-oriented design of learning modules. Procedia CIRP, 32(Clf), 7-12. https://doi.org/10.1016/j.procir.2015.02.211

Estriyanto, Y., Kersten, S., Pardjono, P., \& Sofyan, H. (2017). The missing productive vocational high school teacher competency standard in the Indonesian education system THE MISSING PRODUCTIVE VOCATIONAL HIGH SCHOOL TEACHER COMPETENCY STANDARD IN THE INDONESIAN Sebelas Maret University , Indonesia Technische Univer. Journal of Technical Education and Training (JTET), 9(1), 26-44.

Gendall, J. (2008). 21st-Century Newsroom Design. Pro AV, 25(3), 15.

Heinich, R., Molenda, M., Russell, J., \& Smaldino, S. (2012). Instructional Media and Technology for Learning. International Journal of Distributed and Parallel Systems. https://doi.org/10.1016/J.ARABJC.2011.11.008

Hsu, T. Y., \& Chen, C. M. (2010). A mobile learning module for high school fieldwork. Journal of Geography. https://doi.org/10.108o/oo221341.2010.480941

Hwang, W. Y., Chen, N. S., Dung, J. J., \& Yang, Y. L. (2007). Multiple representation skills and creativity effects on mathematical problem solving using a multimedia whiteboard system. Educ. Technol. Soc, 10, 191-212.

Johnston, N. (2010). Is an online learning module an effective way to develop information literacy skills? Australian Academic and Research Libraries, 41(3), 207-218. https://doi.org/10.1080/00048623.2010.10721464

Karnain, R., Rahman, S., Surat, S., \& Ali, M. T. (2019). Usability of M-PA21 module to improve teachers' metacognitive regulation in teaching and application of 21st century basic skills. International Journal of Emerging Technologies in Learning, 14(20), 87-105. https://doi.org/10.3991/ijet.v14i20.11462

Li, M., \& Ren, Y. (2018). A multimedia teaching model for "Sports Statistics" based on ARCS motivation theory. International Journal of Emerging Technologies in Learning, 13(9), 15-28. https://doi.org/10.3991/ijet.v13iog.8972

Mirzianov, O., Mitasiunas, A., Novickis, L., \& Ragaisis, S. (2016). Development and Validation of Learning Process Assessment Model. Procedia Computer Science, 104(December 2016), 258-265. https://doi.org/10.1016/j.procs.2017.01.133

Perzyk, M., \& Kozlowski, J. (2018). Intelligent production data analytics for metal industry 4.o. In METAL 2018 27th International Conference on Metallurgy and Materials, Conference Proceedings. 
Prasetya, D. D., \& Hirashima, T. (2018). Design of multimedia-based digital storybooks for preschool education. International Journal of Emerging Technologies in Learning, 13(2), $211-225$. https://doi.org/10.3991/ijet.v13io2.8188

Reiser, R. A., \& Gagné, R. M. (1982). Characteristics of Media Selection Models. Review of Educational Research. https://doi.org/10.3102/00346543052004499

Richey, R. C., \& Klein, J. D. (2005). Developmental research methods: Creating knowledge from instructional design and development practice. Journal of Computing in Higher Education, 16(2), 23-38. https://doi.org/10.1007/BFo2961473

Setiadi, B R, Nuryanto, A., \& Ahmad, N. D. (2020). The proofing validation of conventional mechanical drawing job sheet. Journal of Physics: Conference Series, 1446, 012027. https://doi.org/10.1088/17426596/1446/1/012027

Setiadi, Bayu Rahmat, Subagyo, S., Johan, A. B., Nurtanto, M., Sugiyono, S., \& Nurdiyanto, H. (2019). Mobile pocketbook of the ${ }_{4} \mathrm{Cs}$ skills-oriented inform of Quick Response Code. In ICOSS 2018. EAI EUDL. https://doi.org/10.4108/eai.21-9-2018.2281182

Setuju, Ratnawati, D., Wijayanti, A., Widodo, W., \& Setiadi, B. R. (2020). ICT-based learning media development. Journal of Physics: Conference Series, 1446, o12038. https://doi.org/10.1088/1742-6596/1446/1/012038

Setuju, S., Setiadi, B. R., Rantnawati, D., \& Widowati, A. (2019). The Development Digital Book for Vocational High Schools. International Journal of Recent Technology and Engineering, 8(1C2), 802-806.

Sudira, P. (2014). Indonesia vocational education praxis betwen. In Empowering Vocational Education and Training to Elevate National Economic Growth (pp. 190-200). Yogyakarta: UNY. Retrieved from http://eprints.uny.ac.id/24466/1/A-27.pdf

Sugiyono. (2013). Metode Penelitian Pendidikan. Bandung: CV. Alfabeta.

Vina Serevina, Sunaryo, Raihanati, I Made Astra, I. J. S. (2018). Development of E-Module Based on Problem Based Learning (PBL) on Heat and Temperature to Improve Student's Science Process Skill. TOJET: The Turkish Online Journal of Educational Technology -.

Yarkova, T. A., Cherkasova, I. I., Timofeeva, A. M., Cherkasov, V. V., \& Yarkov, V. G. (2017). Preparing teachers to use new media visual communications in education. International Journal of Emerging Technologies in Learning, 12(2), 4-15. https://doi.org/10.3991/ijet. v12io2.6133

Zhai, W. (2018). Design and application of a remote electronic communication teaching system in a network environment. International Journal of Emerging Technologies in Learning, 13(4), $200-208$. https://doi.org/10.3991/ijet.v13io4.848o 